\title{
Predation on young treefrog (Osteocephalus taurinus) by arthropods (Insecta, Mantodea and Arachnida, Araneae) in Central Brazil
}

\author{
Raul Costa-Pereira ${ }^{1,5}$, Fernando Ibanez Martins ${ }^{2}$, Eurico Antonio Sczesny-Moraes ${ }^{3} \&$ Antonio Brescovit $^{4}$ \\ ${ }^{1}$ Centro de Ciências Biológicas e da Saúde - CCBS, \\ Universidade Federal de Mato Grosso do Sul - UFMS, \\ Cidade Universitária s/n, CEP 79070-900, Campo Grande, MS, Brasil \\ ${ }^{2}$ Programa de Pós-graduação em Ecologia e Conservação, \\ Centro de Ciências Biológicas e da Saúde - CCBS, Universidade Federal de Mato Grosso do Sul-UFMS, \\ Cidade Universitária, s/n, CEP 79070-900, Campo Grande, MS, Brasil \\ ${ }^{3}$ Departamento de Patologia, Centro de Ciências Biológicas e da Saúde-CCBS, \\ Universidade Federal de Mato Grosso do Sul - UFMS, \\ Cidade Universitária, s/n, CEP 79070-900, Campo Grande, MS, Brasil \\ ${ }^{4}$ Laboratório de Artrópodes, Instituto Butantan, \\ Av. Vital Brasil, 1500, CEP 05503-900, São Paulo, SP, Brasil \\ ${ }^{5}$ Autor para correspondência: Raul Costa-Pereira, e-mail: brycon@ymail.com
}

COSTA-PEREIRA, R., MARTINS, F.I., SCZESNY-MORAES, E.A. \& BRASCOVIT, A. Predation on young treefrogs (Osteocephalus taurinus) by arthropods (Insecta, Mantodea and Arachnida, Araneae) in Central Brazil. Biota Neotrop. 10(3): http://www.biotaneotropica.org.br/v10n3/en/abstract?shortcommunication+bn04310032010.

\begin{abstract}
Praying mantis and spider species are common food items in the diet of several anuran species. Nevertheless, in this study we report the predation of young treefrogs Osteocephalus taurinus by two spider species, a Pisauridae and a Trechaleidae (Neoctenus sp.) and by the praying mantis Eumusonia sp. in Mato Grosso, Central Brazil. The great abundance of this treefrog in the region, combined with its small body size during the juvenil stage, favor its predation by generalists predators. Indeed, more studies are needed to quantify the real influence of invertebrate predators on anuran populations.
\end{abstract}

Keywords: Eumusonia, Neoctenus, Pisauridae, throphic generalism, Hylidae.

COSTA-PEREIRA, R., MARTINS, F.I., SCZESNY-MORAES, E.A. \& BRASCOVIT, A. Predação de anuros jovens (Osteocephaus taurinus) por artrópodes (Insecta, Mantodea e Arachnida, Araneae) no Brasil Central. Biota Neotrop. 10(3): http://www.biotaneotropica.org.br/v10n3/pt/abstract?shortcommunication+bn04310032010.

Resumo: Espécies de aranhas e louva-a-deus são itens alimentares de diversas espécies de anuros. Porém, aqui reportamos a predação de jovens anuros da espécie Osteocephalus taurinus, por duas espécies de aranha, uma Pisauridae e uma Trechaleidae (Neoctenus sp.), e por um louva-a-deus Eumusonia sp. em Mato Grosso, Brasil Central. A grande abundância desse anuro na região, aliada a seu pequeno porte durante a fase juvenil, favorece sua predação por invertebrados generalistas. Entretanto, mais estudos devem ser conduzidos para quantificar a real influência de predadores invertebrados nas populações de anuros.

Palavras-chave: Eumusonia, Neoctenus, Pisauridae, generalismo trófico, Hylidae. 


\section{Introduction}

Anurans have a key role in food webs acting either as important predators or significant preys and linking terrestrial to aquatic ecosystems (Wilbur 1997, Whiles et al. 2006). Several anuran characteristics point out to their importance in ecosystem functioning, such as their great abundance and biomass in Neotropical communities (Duellman 1988), variable body size (Vitt \& Caldwell 2009), vulnerable periods in the life cycle (Toledo 2005), trophic generalism (Solé \& Rödder 2009) and diversity of potential predators (Toledo 2005, Toledo et al. 2007).

Predation is one of the greatest causes of mortality in anuran natural populations and can occur in any life history stage (Zug et al. 2001). A wide range of organisms have been described as anuran predators, including both invertebrates and vertebrates (Duellman \& Trueb 1994, Zug et al. 2001, Toledo et al. 2007). However, as mentioned by Toledo (2005), reports on predation by invertebrates are usually anecdotal. In a recent review, Toledo (2005) reported 68 species of post-metamorphosed anurans preyed by 57 invertebrate species, mostly by aquatic predators, such as spiders and water bugs.

Osteocephalus taurinus is an abundant treefrog in Central and North Brazil, and most predation registers are from the Amazon rainforest. Tadpoles are mostly preyed by fish and dragonfly larvae (Gascon 1992), while juvenile and adults are chiefly preyed by vertebrates. Vertebrate predators include the squirrel cuckoo Piaya cayana (Cintra \& Sanaiotti 1990) and bats (Amézquita \& Hödl 2004).

In many anuran trophic studies, arthropods are common food items (Araújo et al. 2007, Mahan \& Johnson 2007, Santana \& Juncá 2007). However, the present short communication reports predation on young treefrog Osteocephalus taurinus Steindachner, 1862 by arthropods: two spider species and a praying mantis, in Central Brazil.

\section{Material and Methods}

The study was carried out in the filling period of the Pequena Central Hidrelétrica Bocaiúva Dam (12 32' 56" S and 57 52'25” W), a small hydroeletric plant in Brasnorte municipality, Mato Grosso, Brazil, in November 2009. The observations took place in the flooded area surrounding the Cravari River, a region of wet grassland vegetation, savannah and gallery forests. The flood, led by damming, causes vertebrates and invertebrates to shift from their natural microhabitats to higher sites, not yet submerged. Therefore, there is an alteration in the natural dynamics of these ecosystems, restricting the animals movements. Hence, the organisms isolated by the flooding aggregate at the scarce higher sites (e.g. shrubs or tree branches) that remain above the water level. These sites resembles metacommunities on ephemeral islands. The water level rise causes a constant area reduction in the remnant refugee sites, especially for terrestrial and fossorial animals.

Field data collection occurred always between 9:00 and 11:00 AM and after 5:00 PM. We report the predation events by pictures, taken with a Sony DSC H-20 camera. Both predators and prey were not collected and the identifications were made through the photographs. One hundred young individuals of the treefrog O. taurinus were measured in the same site where the predation events occured. Once anurans show a small variation in body lenght, we used the average length to calculate, by proportion, the predators sizes in the pictures.

\section{Results and Discussion}

We observed three predation events on the young treefrog Osteocephalus taurinus by three arthropods morphospecies: the praying mantis Eumusonia sp. and the spiders Neoctenus sp. (Trechaleidae) and a not identified Pisauridae.
The mantis Eumusonia sp. (Thespidae, Thespinae) was an adult female, measuring approximately $48 \mathrm{~mm}$. The praying mantis was holding the treefrog with its raptorial forelegs, the tree frog was apparently dead (Figure 1a). Since praying mantis catching is stimulated by preys' movement, we suggest that the treefrog was alive when captured, although we did not observe it.

Mantis predation role is well known in literature; however, reports of mantids preying anurans are scarce. Hathaway (1946) registered the Mantodea Stagmatoptera precaria preying the small anuran Scinax fuscovarius in laboratory conditions. Ridpath (1977) registered the Mantodea Archimantis latistyla preying the anuran Litoria raniformis, but the microhabitat in which the predation event occurred was not specified.

The spider Neoctenus sp. (Trechaleidae) measured approximately $40 \mathrm{~mm}$ length, and we observed one individual of this species preying a young $O$. taurinus on a palm tree leaf (Figure $1 \mathrm{~b}$ ). The Pisauridae spider, measured approximately $18 \mathrm{~mm}$ length, and was observed catching and manipulating the treefrog in Cerrado riparian forest (Figure 1c).

Reports of anuran predation by spiders constitute the majority cases of invertebrate predators of anurans in scientific literature (Toledo 2005). Several cases are from the Neotropical region (Menin et al. 2005, Pombal Jr. 2007, Barbo et al. 2009) and Africa (Vonesh 2005, Barej et al. 2009). In review, Toledo (2005) reported eight families of Araneae which prey upon anurans, highlighting the family of fishing spiders, Pisauridae. Menin et al. (2005) also confirms Pisauridae as important predators of anurans. These spiders have nocturnal opportunist predator habits, and are generally found near aquatic environments (Höfer \& Brescovit 2000). Information about hunting behavior of Trechaleidae spiders are scarce (Höfer \& Brescovit 1994, Silva et al. 2005), however anurans have been recorded as prey (Schiesari et al. 1995).

The treefrog $O$. taurinus was very abundant in our study site. A recent reproduction event, typical to O. taurinus (Hödl 1990) could explain it. During our observations, the mean snout-vent length of young $O$. taurinus was $15 \mathrm{~mm}(\mathrm{SD}=2 \mathrm{~mm}, \mathrm{n}=100)$, and mean body mass $0.375 \mathrm{~g}(\mathrm{SD}=0.057 \mathrm{~g}, \mathrm{n}=100)$. Toledo (2005) discuss that in this life cycle period, when recent young anurans leave the water, predation risk is increased.

In our report, the three arthropod predators were larger than the predated frogs. This was also observed in $34 \%$ of the records reviewed by Toledo et al. (2007). The relationship between prey and predator size is an important determinant of predation pressure (Toledo et al. 2007). In this way, young anurans, usually with small body size and weight, are potential prey to invertebrate predators.

The predation events described in this study highlight the generalist and trophic opportunism of spiders and praying mantids (Reitze \& Nentwig 1991, Gonzaga et al. 2007). Thus, diet composition may be related to resources availability (Riechert 1991, Mihuc \& Minshall 1995). Moreover, the great abundance of $O$. taurinus in the islands formed by the flooding, added to the small escape possibility and the absence of microhabitats for hiding, makes the treefrog O. taurinus a potential prey for generalist predators.

The role of invertebrates as predators of tadpoles is well documented in the aquatic environment. These studies have shown these predators can modify, potentially, the composition of tadpole assemblages and phenotipic features through differential predation efforts (Gascon 1992, McCollum \& Leimberger 1997, Hero et al. 2001). However, considering metamorphosed anurans, the absence of quantitative data makes it difficult to establish the real influence of invertebrate predators in the anuran population dynamics (McCormick \& Polis 1982). In this way, we believe that the predation on young anurans by invertebrates may also have an important role in their population's dynamics, mainly considering the high abundance of both in Neotropical communities. 

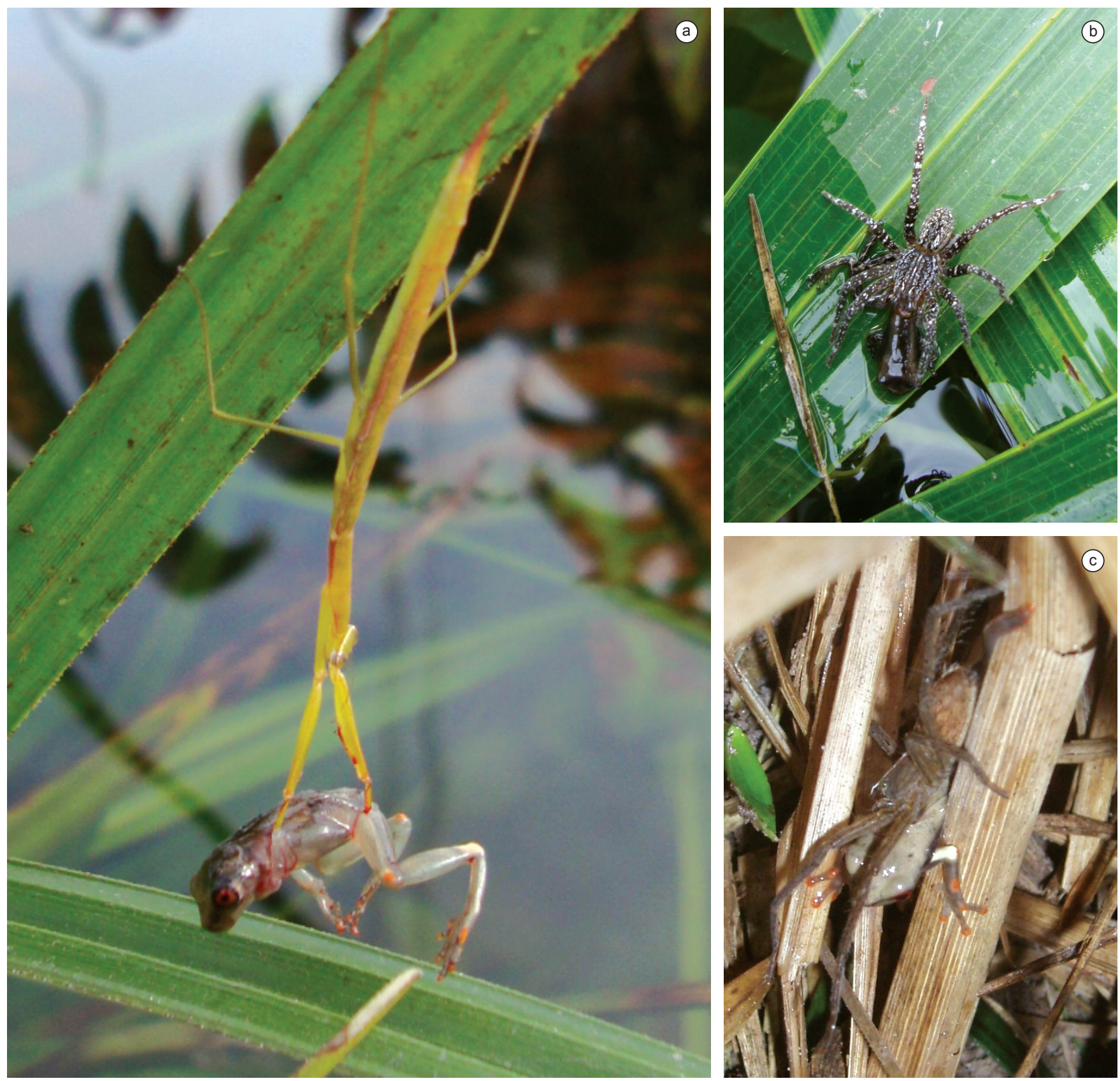

Figure 1. a) The praying mantis Eumusonia sp. manipulating a young Osteocephalus taurinus in Central Brazil. Photo: Raul Costa Pereira; b) The spider Neoctenus sp. (Trechaleidae) preying a young Osteocephalus taurinus in Central Brazil. Photo: Larissa S.M. Sugai; and c) Spider (Pisauridae) preying a young Osteocephalus taurinus in Central Brazil. Photo: Eurico A. Sczesny-Moraes.

\section{Acknowledgements}

The authors are grateful to Paul S. Terra and Ana Luiza Cesquim Campos for genteelly identifying the Mantodea and anurans respectively, and Fibra Consultoria, Perícias e Projetos Ambientais for the field support. We also thank Larissa Sugai and Luciana Vicente for their help in the field work; Natália C. Campos and Karla Campião for the correction/ translation help. To editor and anonymous referees for the critical reading and valuable suggestions. The authors are grateful to $\mathrm{CNPq}$.

\section{References}

AMÉZQUITA, A. \& HÖDL, W. 2004. How, when, and where to perform visual displays: the case of the amazonian frog Hyla parviceps. Herpetologica 60(4):420-429.
ARAÚJO, M.S., REIS, S.F., GIARETTA, A.A., MACHADO, G. \& BOLNICK, D.I. 2007. Intrapopulation diet variation in four frogs (Leptodactylidae) of the Brazilian savannah. Copeia 4:855-865.

BARBO, F.E., RODRIGUES, M.G., COUTO, F.M. \& SAWAYA, R.J. 2009. Predation on Leptodactylus marmoratus (Anura: Leptodactylidae) by the spider Ctenus medius (Araneae: Ctenidae) in the Atlantic Forest, Southeast Brazil. Herpetol. Notes 2:99-100.

BAREJ, M.F., WURSTNER, J.A.M. \& BOHME, W. 2009. Predation on the treefrog Leptopelis brevirostris (Anura: Arthroleptidae) by a wandering spider (Araneae: Ctenidae) in Cameroon. Herpetol. Notes 2:137-139.

CINTRA, R. \& SANAIOTTI, T.M. 1990. Osteocephalus taurinus (Tree Frog) Predation. Herpetol. Review 21:59.

DUELLMAN, W.E. \& TRUEB, L. 1994. Biology of amphibians. $2^{\text {nd }}$ ed. Johns Hopkins University Press, Baltimore. 
DUELLMAN, W.E. 1988. Patterns of species diversity in anuran amphibians in the American Tropics. Ann. Mo. Bot. Gard. 75:79-104.

GASCON, C. 1992. Aquatic Predators and Tadpole Prey in Central Amazonia: Field Data and Experimental Manipulations. Ecology 73(3):971-980.

GONZAGA, M.O, SANTOS, A.J. \& JAPYASSÚ, H.F. 2007. Ecologia e comportamento de aranhas. Interciência, Rio de Janeiro.

HATHAWAY, C.R. 1946. Considerações sobre a Biologia da Stamatoptera precaria (Linné, 1958) (Mantodea: Mantidae: Vatinae). Mem. I. Oswaldo Cruz 44(1):105-117.

HERO, J., MAGNUSSON, W.E., ROCHA, C.D.E \& CATTERALL, C.P. 2001. Antipredador defences influence the distribuition of Amphibian prey species in the Central Amazon Rain Forest. Biotropica 33(1):131-141.

HÖDL, W. 1990. Reproductive diversity in Amazonia lowland frogs. Forts. Zool. 38:42-60.

HÖFER, H. \& BRESCOVIT, A.D. 1994. On the spider genus Rhoicinus (Araneae,Trechaleidae) in a central amazonian inundation forest. J. Arachnol. 22:54-59.

HÖFER, H. \& BRESCOVIT, A.D. 2000. A revision of the Neotropical spider genus Ancylometes Bertkau (Araneae: Pisauridae). Insect Syst. Evol. 31:323-360.

MAHAN, R.D. \& JOHNSON, J.R. 2007. Diet of the gray treefrog (Hyla versicolor) in relation to foraging site location. J. Herpetol. 41(1):16-23.

McCOLLUM, S.A. \& LEIMBERGER, J.D. 1997. Predator-induced morphological changes in an amphibian: predation by dragonflies affects tadpole shape and color. Oecologia 109:615-621.

McCORMICK, S. \& POLIS, G.A. 1982. Arthropods that prey on vertebrates. Biol. Rev. Camb. Philos. 57:29-58.

MENIN, M., RODRIGUES, D.J. \& AZEVEDO, C.S. 2005. Predation on amphibians by spiders (Arachnida, Araneae) in the Neotropical region. Phyllomedusa 4(1):39-47.

MIHUC, T.B. \& MINSHALL, G.W. 1995. Trophic generalists vs. trophic specialists: Implications for food web dynamics in post-fire streams. Ecology 76(8):2361-2372.

POMBAL Jr., J.P. 2007. Notas sobre predação em uma taxocenose de anfíbios anuros no sudeste do Brasil. Rev. Bras. Zool. 24(3):841-843.

REITZE, M. \& NENTWIG, W. 1991. Comparative investigations into the feeding ecology of six Mantodea species. Oecologia 86:568-574.
RIDPATH, M.G. 1977. Predation on frogs and small birds by Hierodula werneri (Gigliotos, Mantidae) in Tropical Australia. J. Aust. Entomol. Soc. 16:153-154.

RIECHERT, S.E. 1991. Prey abundance vs diet breadth in a spider test system. Evol. Ecol. 5:327-338.

SANTANA, A.S. \& JUNCÁ, F.A. 2007. Diet of Physalaemus cf. cicada (Leptodactylidae) and Bufo granulosus (Bufonidae) in a semideciduous forest. Braz. J. Biol. 67(1):125-131.

SCHIESARI, L.C.; JUNCÁ, F.A. \& ACCACIO, G.M. 1995. Hylodes phyllodes (NCN). Predation. Herpetol Rev. 26(1):30-31.

SILVA, E.L.C., PICANÇO, J.B. \& LISE, A.A. 2005. Notes on the predatory behavior and habitat of Trechalea biocellata (ARANEAE, LYCOSOIDEA, TRECHALEIDAE). Biociências 13(1):85-88.

SOLÉ, M. \& RÖDDER, D. 2009. Dietary assessments of adult amphibians. In Amphibian ecology and conservation: A handbook of techniques (C.K. Dodd Jr., ed.). Oxford University Press, Oxford, p.167-184.

TOLEDO, L.F. 2005. Predation of juvenile and adult anurans by invertebrates: current knowledge and perspective. Herpetol. Review 36(4):395-400.

TOLEDO, L.F., RIBEIRO, R.S. \& HADDAD, C.F.B. 2007. Anurans as prey: an exploratory analysis and size relationships between predators and their prey. J. Zool. 271:170-177.

VITT, L.J. \& CALDWELL, J.P. 2009. Herpetology. Academic Press, New York.

VONESH, J.R. 2005. Sequential predator effects across three life stages of the African tree frog, Hyperolius spinigularis. Oecologia. 143:280-290.

WHILES, M.R., LIPS, K.R., PRINGLE, C.M., KILHAM, S.S., BIXBY, R.J., BRENES, R., CONNELLY, S., COLON-GAUD, J.C., HUNTEBROWN, M., HURYN, A.D., MONTGOMER,Y.C. \& PETERSON, S. 2006. The effects of amphibian population declines on the structure and function of Neotropical stream ecosystems. Front. Ecol. Environ. 4:27-34.

WILBUR, H.M. 1997. Experimental ecology of food webs: Complex systems in temporary ponds. Ecology 78(8):2279-2302.

ZUG, G.R., VITT, L.J. \& CALDWELL, J.P. 2001. Herpetology: An introductory biology of amphibians and reptiles. $2^{\text {nd }} e d$. Academic Press, San Diego. p.275-298. 